\title{
Upstream Hydraulic Interconnection Study of Gunungkidul Karst Area Underground Rivers
}

\author{
Studi Keterhubungan Hidrolika Hulu Sungai-Sungai Bawah Tanah Daerah \\ Karst Gunungkidul
}

\author{
Paston Sidauruk*, Satrio, Evarista Ristin Pujiindiyati, Barokah Aliyanta \\ Pusat Aplikasi Isotop dan Radiasi-BATAN, Jl. Lebak Bulus Raya No. 49, Ps. Jumat, Jakarta, Indonesia, 12440 \\ *E-mail: pastons@batan.go.id
}

Article received: 19 Oktober 2017, revised: 15 November 2017, accepted: 30 November 2017

DOI: https://doi.org/10.17146/eksplorium.2017.38.2.3715

\begin{abstract}
Hydraulic interconnection of Jomblangan cave (Petung) with other caves and water discharges in Gunungkidul karst area has been investigated using tracer techniques and variationof stable isotopes and hydrochemical data interpretation from water samples near the cave. Many studies related to the interconnections of underground rivers around Gunungkidul Karst area have been conducted, most of them, however, focused on the area around Bribin and Seropan caves. This is because of the development activites of microhydro turbines to lift the water from underground river were still focused around Bribin and Seropan caves. Petung cave, located in the north of Bribin and Seropan caves, was believed to be one of the caves at the upstream river system of Bribin and Seropan, however, there is no evidence yet of the hydraulic interconnection between Petung cave with either Bribin or Seropan caves. The results of tracer technique at the current study showed that there was no hydraulic interconnection between Petung cave with either Bribin and Seropan caves.On the other hand, the study showed an indication of a direct flow from Petung cave to Sriti and Beton springs. The travel times from Petung to Sriti and Beton springs were found to be around 2 and 10 hours, respectively. This finding is also in agreement with the results of chemical and stable isotopes analysis from the research location.
\end{abstract}

Keywords: Gunungkidul, karst, deuterium, oxygen-18, hydrochemistry, tracer test, underground river, caves.

\begin{abstract}
ABSTRAK
Penelitian keterhubungan Gua Jomblangan (Petung) dengan gua lainnya dan keluaran air di sekitar daerah karst Gunungkidul telah dilakukan dengan menggunakan teknik perunut dan variasi kandungan isotop stabil serta hidrokimia sampel air di sekitar gua. Penelitian yang berkaitan dengan keterhubungan antara sistim aliran bawah tanah di sekitar daerah karst Gunungkidul telah banyak dilakukan, namun sebagian besar dari penelitian tersebut hanya berpusat pada gua di sekitar Bribin dan Seropan. Hal ini terjadi karena kegiatan pembangunan turbin-turbin mikrohidro untuk mengangkat air dari sungai bawah permukaan tanah masih terfokus di daerah gua Bribin dan Seropan. Gua Petung, yang berada di sebelah utara gua Bribin dan Seropan, dipercaya merupakan salah satu gua yang berada di hulu sistim sungai bawah tanah Bribin dan Seropan, namun, sampai sekarang belum ada bukti keterhubungan hidrolika antara gua Petung dengan gua Bribin maupun dengan gua Seropan.Hasil uji perunut dalam penelitian ini menunjukkan bahwa aliran air bawah tanah di gua Petung tidak berhubungan langsung dengan aliran bawah tanah di gua Bribin maupun di gua Seropan. Sebaliknya, hasil penelitian ini menunjukkan adanya aliran langsung dari gua Petung ke mata air Sriti dan Beton. Waktu tempuh yang dibutuhkan dari gua Petung ke mata air Sriti adalah sekitar 2 jam dan ke mata air Beton adalah sekitar 10 jam. Temuan ini sangat bersesuaian dengan hasil analisis kimia air dan isotop stabil dari lokasi penelitian.
\end{abstract}

Kata kunci: Gunungkidul, karst, deuterium, oksigen-18, hidrokimia, uji perunut, sungai bawah tanah, gua. 


\section{INTRODUCTION}

Population and industrial activities growth will cause the increase of the need of water as well as the deterioration of water quality. In general, it has been reported that the access of population of Indonesia to improved water has increased significantly. The access of Indonesian to improved water has significantly increased from only $70 \%$ in 1990 to $82 \%$ in 2010 [1]. In Gunungkidul as depicted in Figure 1, however, the access of the population to improved water facilities is still considered to be low. This is because Gunungkidul karst area has limited available water sources. The capability of the soil in the study area to retain the water is very limited due to the fact that the geological sturucture is dominated by karst formation. Although the annual rain intensity in the area is considered to be very high that is around $2000 \mathrm{~mm}[2,3]$, almost all the rain water immediately seeps through karst fractures into underground river deep below ground surface $[4,5]$. For many years, the population of Gunungkidul has relied on rain water harvesting and water from underground river discharges as the main sources to fulfil its water demand. Hence, the population of Gunungkidul is very often confronted with water scarcity especially in dry season [6]. Rainwater harvesting is only available in rainy season that make water from underground river will be the only feasible main water sources that available all year long for domestic, agriculture, and industrial water needs. Many studies to explore the potential of underground river as the main water source have been conducted by many researchers. Adji and Sudarmadji reviewed some previous studies about the potential of underground river as the main water sources in Gunungkidul karst area [7]. The researchers from Center for Isotopes and Radiation
Application has studied the recharge area elevations of some main underground rivers systems around Gunungkidul karst area using the variations of stable isotopes ( $\delta D$ and $\delta^{18} \mathrm{O}$ ) of those samples collected from rain collectors, caves, and other water outlets as a function of time and space [8].

In interconnection studies, the main task is to establish the network of underground river systems. The main questions that need to be answered in establishing the underground river systems such as (i). where does the water go and come?; (ii). What is the travel time of the water from one cave to other caves? Sidauruk, Prasetio, and Satrio has tried to answer some of these questions by conducting series of tracer tests using rhodamine WT to establish quantitative hydraulic interconnection among SeropanBribin-Ngreneng underground rivers [9] Some of previous studies have successfully established the interconnections of some underground river systems, however, most of the studies have focused mainly on the downstream hydraulic interconnection of Bribin and Seropan underground river system. Little has known about the hydraulic interconnection of underground river systems at the upstream of Bribin and Seropan underground rivers. The current study aimed to study the upstream hydraulic interconnection of Bribin and Seropan underground river systems using tracer tests. For comprehensive results, the hydraulic interconnection of underground river systems will also be interpreted based on stable isotopes and hydrochemistry contents and their variations of all samples collected in the study area. The results of this study will give important information to the stake holders to implement sustainable management in development of underground river in Gunungkidul karst area. 


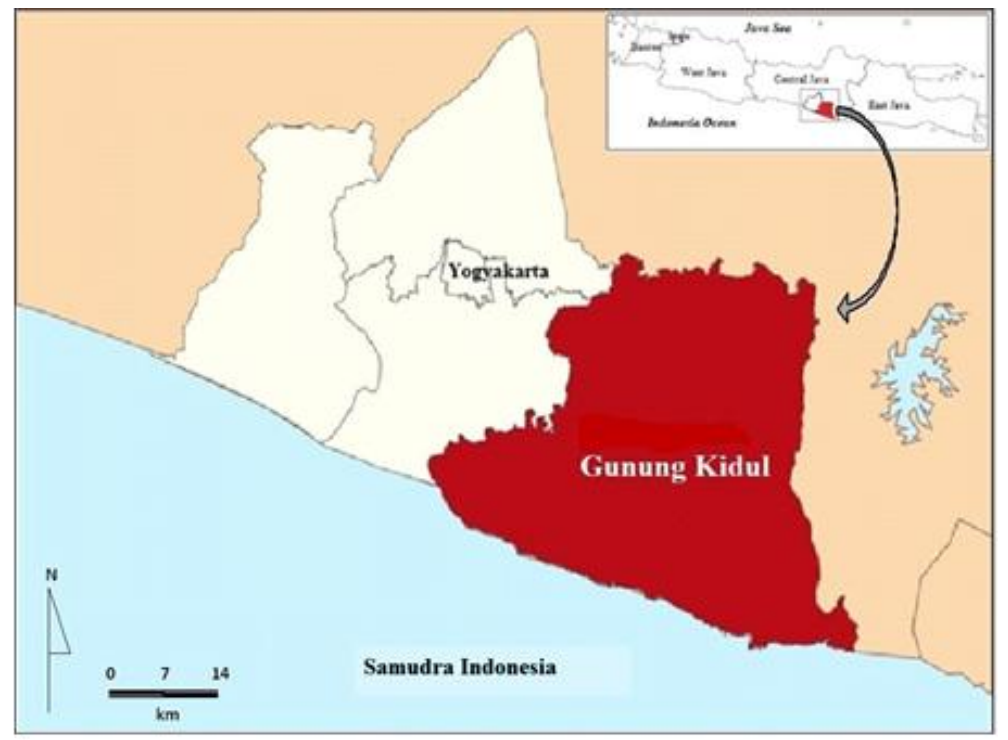

Figure 1. Location of the study.

\section{METHODOLOGY}

\section{Collection of Samples}

Water samples were collected at predetermined locations as depicted in Figure 2. The samples were collected for stable isotopes and hydrochemical contents analysis. For stable isotopes analysis, about $20 \mathrm{ml}$ of water from each sampling points were collected and put into small clear container with air tide cap. For hydrochemical analysis, about $500 \mathrm{ml}$ of water were collected from each sampling points. The collected samples were sent to the Center for Isotopes and Radiation Application-BATAN laboratory in Jakarta to be analyzed. At the current study, sampling campaign was conducted twice from each sampling point during January to December 2012 period.

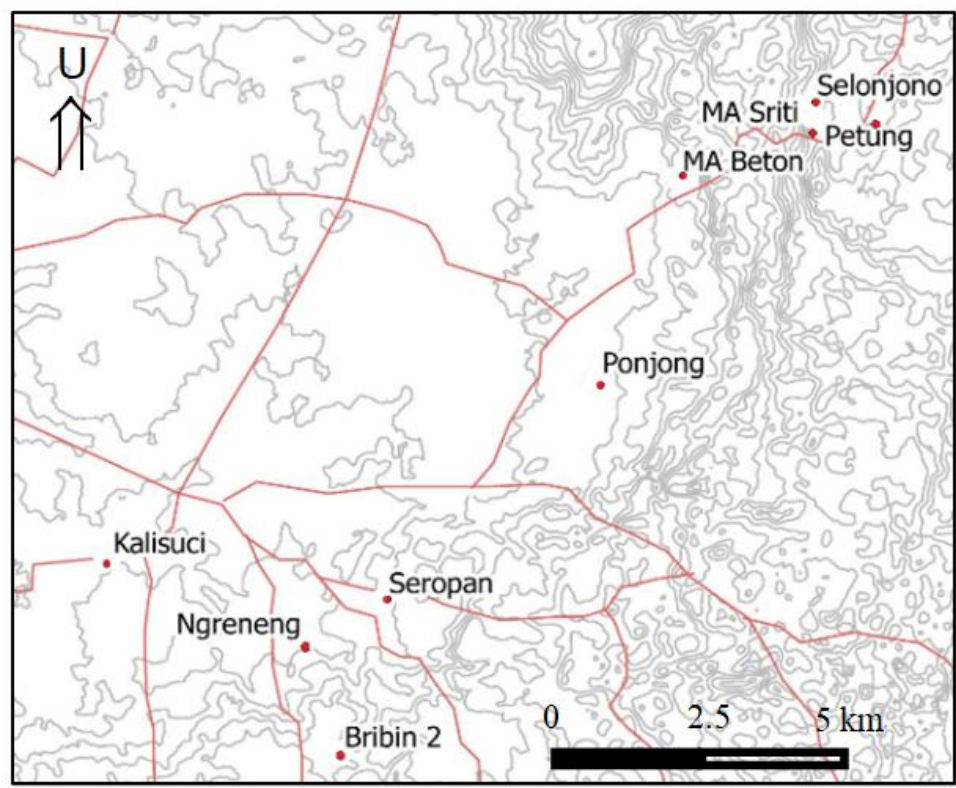

Figure 2. Location of sampling points. 


\section{Stable Isotopes and Hydrochemistry}

Stable isotopes relative contents are very important to trace back the physical processes that the water has undergone before exiting at the sampling point. Hydrochemical contents of collected samples are very important parameters to trace back the geological formation that water has passed through due to the fact that water is a good solvent[10]. Stable isotopes and hydro-chemical contents of collected water samples were analyzed at the Center for Isotopes and Radiation Application-BATAN Laboratory in Jakarta. Stable isotopes relative contents ( $\delta D$ and $\delta^{18} O$ ) were analyzed using LGR laser spectrometer. The hydrochemical contents were analyzed using Metrohm ion chromatography. Piper diagram will be used to present hydrochemical data to give a better understanding of the variation of hydrochemical data [11].

Due to overwhelming abundance of lighter water molecule $\left(\mathrm{H}_{2}{ }^{16} \mathrm{O}\right)$ compared to the heavier molecules (i.e., $\mathrm{HD}^{16} \mathrm{O}, \mathrm{H}_{2}{ }^{18} \mathrm{O}$ ), measuring absolute contents of each molecule is not feasible. For this reason, only relative contents of $\mathrm{H}_{2}{ }^{16} \mathrm{O}, \mathrm{H}_{2}{ }^{18} \mathrm{O}$ with respect to $\mathrm{H}_{2}{ }^{16} \mathrm{O}$ will be considered. The relative contents of $\mathrm{HD}^{16} \mathrm{O}$ and $\mathrm{H}_{2}{ }^{18} \mathrm{O}$ with respect to $\mathrm{H}_{2}{ }^{16} \mathrm{O}$ is normally called deuterium ratio $(\delta D)$ and oxygen-18 ratio $\left(\delta^{18} O\right)$, respectively and is given in equations 1 and 2 [12].

Deuterium ratio $(\delta D)$ in:

$$
\begin{aligned}
& \delta D=\left(\frac{R_{D(\text { sample })}}{R_{D(\text { standard })}}-1\right) \times 1000 \% \text {; } \\
& R_{D}=\frac{N(H D O)}{N\left(H_{2} \mathrm{O}\right)}
\end{aligned}
$$

Oxygen-18 ratio $\left(\delta^{18} O\right)$ :

$$
\begin{gathered}
\delta^{18} O=\left(\frac{R^{18} O_{\text {(sample) }}}{R^{18} O_{\text {(standard) }}}-1\right) \times 1000 \% \\
R^{18} O=\frac{N\left(H_{2}{ }^{18} \mathrm{O}\right)}{N\left(\mathrm{H}_{2} \mathrm{O}\right)}
\end{gathered}
$$

In which $R_{D}$ and $R^{18} O$ are the molecule ratios for deuterium and oxygen-18, respectively and $N(x)$ is absolute content of the molecule $x$.

\section{Tracer Tests}

The tracer used in this study was rhodamine WT. Rhodamine WT is a bright fluorescent red dye usually used for water tracing applications such as rate, direction, and leakage of flow. Rhodamine WT is one of the tracer that has been approved to be used as a tracer in potable water in USA. After a very careful examination of physical and chemical properties as well as the health impact (sensitivity, minimum detectability, water chemistry effect, photochemical and biological decay rates, adsorption losses, toxicity) of eight fluorescents tracers (amino $\mathrm{G}$ acid, photine $\mathrm{CU}$, fluorescein, lissamine $\mathrm{FF}$, pyranine, rhodamine $\mathrm{B}$, rhodamine $\mathrm{WT}$, and sulphorhodamine B), Smart and Laidlaw highly recommended rhodamine WT to be used as a tracer in water tracing application besides lissamine FF and amino G acid [13]. Rhodamine WT is available in the market as a $20 \%$ solution in water with specific gravity about 1.19 . In view of these dye evaluations and recommendations, for the last several years, Indonesia has adopted rhodamine WT as a main dye for water tracing applications such as to study the interconnection of Seropan, Bribin, and Ngreneng caves in Gunungkidul karst area [9] and to measure flow rate of Mrican irrigation canals as an effort to perform field calibration of existing weirs [14]. 
In this study, the tracer test was conducted by injecting about 11 of rhodamine WT at Petung cave at about 12.45 on March 16, 2012 as given Table 1 together with location of sampling points. Immediately after the injection of tracer, water samples were collected at predetermined sampling points as listed in Table 1. The collected samples were analyzed in situ using portable fluorometer Turner Design Instrument Model 10-AU-005-CE.

Table 1. Tracer tests set up.

\begin{tabular}{llll}
\hline $\begin{array}{c}\text { Injection } \\
\text { point }\end{array}$ & Tracer & $\begin{array}{c}\text { Time of } \\
\text { injection }\end{array}$ & $\begin{array}{c}\text { Observation } \\
\text { points }\end{array}$ \\
\hline Petung & Rhodamine & March 16, & Ngreneng \\
cave & WT & 2012 & cave; Beton \\
& & $(12.45)$ & $\begin{array}{l}\text { pond; Seropan } \\
\text { cave; Bribin } \\
\text { cave; Sriti } \\
\text { springs; Baron } \\
\end{array}$ \\
& & & \\
& & & \\
& & & \\
\end{tabular}

\section{RESULTS AND DISCUSSION}

\section{Tracer Tests}

After injection, rhodamine WT concentrations were observed through periodical sampling at the predetermined sampling points. Periodicity of sampling was determined according to the relative distance of sampling point to injection points. The periodicity was further adjusted when anomaly of rhodamine WT concentrations encountered. After 48 hours of observations, anomaly of rhodamine WT concentrations were only found in Sriti and Beton Springs and all other sampling points has shown no any anomaly. The concentration of rhodamine WT of samples collected from Sriti spring which is about $500 \mathrm{~m}$ west of Petung cave is given in Table 2 and the corresponding breakthrough curve is given in Figure 3. From Figure 3, it can be seen that the travel time of water from Petung cave to Sriti spring is about 2 hours with average flow velocity of about $250 \mathrm{~m} / \mathrm{h}$. Considering all of these phenomena and the fact that observed rhodamine WT concentrations are well above background concentration, it can be said that Petung cave is directly connected with Sriti springs with well-developed conduit.

It is also observed visually that Petung cave and Beton spring is connected, however, breakthrough curve and tabulation of rhodamine WT could not be established because of unpredicted arrival time of the tracer. When the person that were assigned to collect the data arrived on the site when the tracer has completely turned the water ponded around the spring to red without any chance to make any measurement of the concentrations. Hence, travel time from injection point (Petung cave) to Beton spring could only be estimated to be about 10 hours. Considering this estimated travel time and the distance of Beton spring of about $3000 \mathrm{~m}$ south west of injection point, it can be estimated that the average flow velocity from injection point to Beton spring is about 300 $\mathrm{m} / \mathrm{h}$. It is than fair to say that injection point with Beton spring is also directly connected with well-developed conduits.

Table 2. Rhodamine WT concentration at Sriti Spring during tracer tests; Injection on: March, 16, 2012 (12.45)

\begin{tabular}{ccc}
\hline No & Sampling time & Concentration $(\mathbf{p p b})$ \\
\hline 1 & 13.45 & 0 \\
2 & 14.05 & 675 \\
3 & 14.25 & 610 \\
4 & 14.45 & 507 \\
5 & 15.05 & 53 \\
6 & 15.25 & 0.23 \\
7 & 15.45 & 0 \\
\hline
\end{tabular}




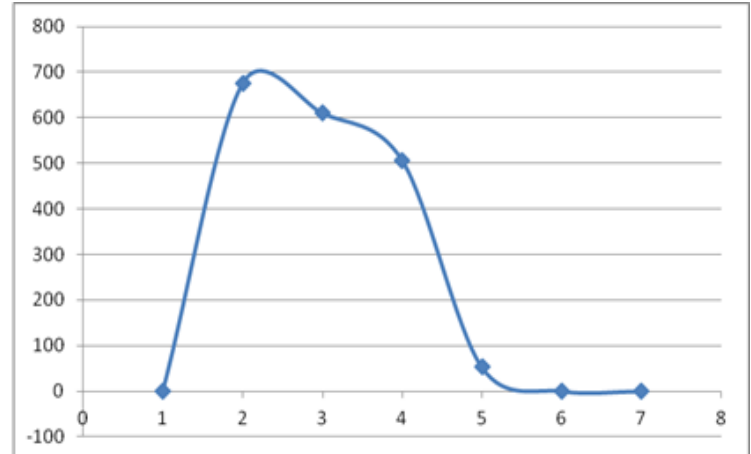

Figure 3. Breakthrough curve rhodamine WT concentration at Sriti spring.

\section{Stable Isotopes}

Deuterium $(\delta D)$ and Oxygen-18 $\left(\delta^{18} O\right)$ ratios of all collected samples are given in Table 3 and the corresponding graph $\delta D$ versus $\delta^{18} O$ is given in Figure 4. From Figure 4 , the regression line equation of $\delta D$ versus $\delta^{18} O$ was found to be $\delta D=3.96 \delta^{18} O-13.26$. The slope of the regression line 3.96 which is much less than the slope of meteoric water line 8 indicates that all of the water has undergone evaporation process.

Table 3. Stable isotopes ratio ( $\delta D$ and $\left.\delta^{18} O\right)$ of collected samples.

\begin{tabular}{|c|c|c|c|}
\hline No. & $\begin{array}{l}\text { Sample } \\
\text { Name }\end{array}$ & $\delta \mathrm{D}(\% / \%)$ & $\delta^{18} \mathrm{O}\left({ }^{0} / 00\right)$ \\
\hline 1 & Beton & -35.8 & -5.80 \\
\hline 2 & Seropan & -36.3 & -6.02 \\
\hline 3 & Sriti & -34.2 & -5.21 \\
\hline 4 & Selonjono & -39.2 & -6.75 \\
\hline 5 & Baron & -38.9 & -6.17 \\
\hline 6 & Ponjong & -40.6 & -6.74 \\
\hline 7 & Bribin & -40.8 & -6.99 \\
\hline 8 & Kali Suci & -36.9 & -6.10 \\
\hline 9 & Ngereneng & -40.1 & -6.75 \\
\hline 10 & Petung & -39.3 & 6.46 \\
\hline
\end{tabular}

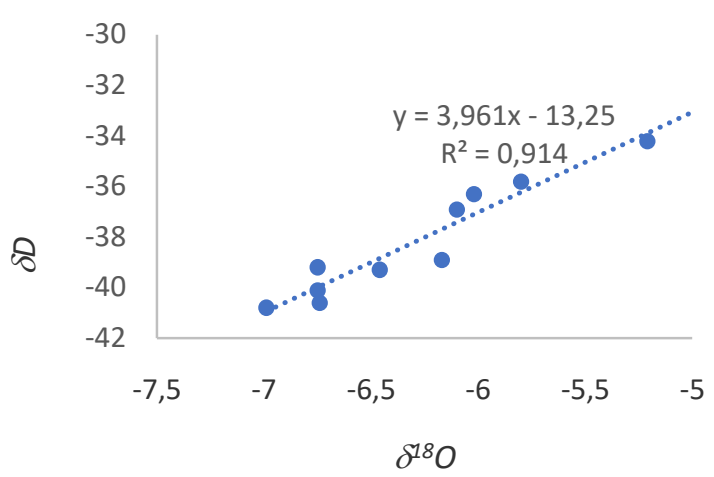

Figure 4. $\delta D$ versus $\delta^{18} O$ of collected samples

This phenomenon makes sense because almost of the water has exposed to the atmosphere i.e., during its flow in open passage, or during its stay in ponds or dead zone of passages. From Table 3, we can observe that the deuterium and oxygen-18 ratios of Bribin cave are much more depleted than the deuterium and oxygen-18 ratios of injection point (Petung cave). This indicates that the water from injection point is not likely to flow to Bribin because in all those water at the downstream of a flow will be normally more enrich rather than more depleted due to evaporation process. This is also in agreement with the results found from tracer test. Other interesting observations from Table 3 is that the deuterium and oxygen-18 ratios of Petung cave are more depleted than those at Sriti and Beton springs. This again indicates that Sriti and Beton springs are at the down streams of Petung cave as also shown by tracer test results.

\section{Hydrochemical Contents}

Hydrochemical contents of all collected data are given in Table 4 and the corresponding Piper diagram is presented in Figure 5. From either Table 4 or Figure 5, the hydrochemical contents of all collected samples do not vary significantly. All the data dominated by calcium and bi-carbonate ions. This indicates that all collected samples have 
been in contact with karst formation before exiting at the sampling points.

Table 4. Hydrochemical data of all collected samples.

\begin{tabular}{llllllll}
\hline \multirow{2}{*}{ No } & \multicolumn{4}{c}{$\begin{array}{c}\text { Cation } \\
\boldsymbol{m g} / \boldsymbol{L}\end{array}$} & \multicolumn{4}{c}{$\begin{array}{c}\text { Anion } \\
\boldsymbol{m g} / \boldsymbol{L}\end{array}$} \\
\cline { 2 - 8 } & $\mathbf{N a}$ & $\mathbf{K}$ & $\mathbf{C a}$ & $\mathbf{M g}$ & $\mathbf{C l}$ & $\mathbf{H C O}_{\mathbf{3}}$ & $\mathbf{S O}_{\mathbf{4}}$ \\
\hline 1 & 4.17 & 1.00 & 65.96 & 14.80 & 5.08 & 221.9 & 3.47 \\
2 & 3.09 & 0.89 & 75.72 & 6.00 & 3.20 & 282.8 & 1.29 \\
3 & 3.74 & 1.02 & 53.10 & 15.20 & 4.08 & 220.9 & 2.47 \\
4 & 3.15 & 0.57 & 62.99 & 7.85 & 2.81 & 249.8 & 2.15 \\
5 & 4.14 & 0.98 & 51.25 & 19.23 & 4.29 & 303.4 & 1.97 \\
6 & 2.17 & 0.96 & 63.94 & 4.45 & 2.75 & 189.4 & 1.26 \\
7 & 2.72 & 0.99 & 68.58 & 14.91 & 3.00 & 290.9 & 1.62 \\
8 & 4.16 & 0.80 & 53.31 & 7.48 & 6.85 & 181.1 & 2.21 \\
9 & 3.09 & 0.87 & 60.67 & 9.40 & 3.08 & 219.9 & 1.47 \\
10 & 3.85 & 1.03 & 48.49 & 13.80 & 2.60 & 252.1 & 2.29 \\
\hline \multicolumn{2}{l}{ Note: 1. Beton spring; 2. Seropan cave; 3. Sriti spring; 4. } \\
\multicolumn{3}{l}{ Selonjono spring; 5. Baron cave; 6. Ponjong spring; 7. Bribin } \\
cave; 8. Kali suci; 9. Ngreneng cave; 10. Petung cave
\end{tabular}

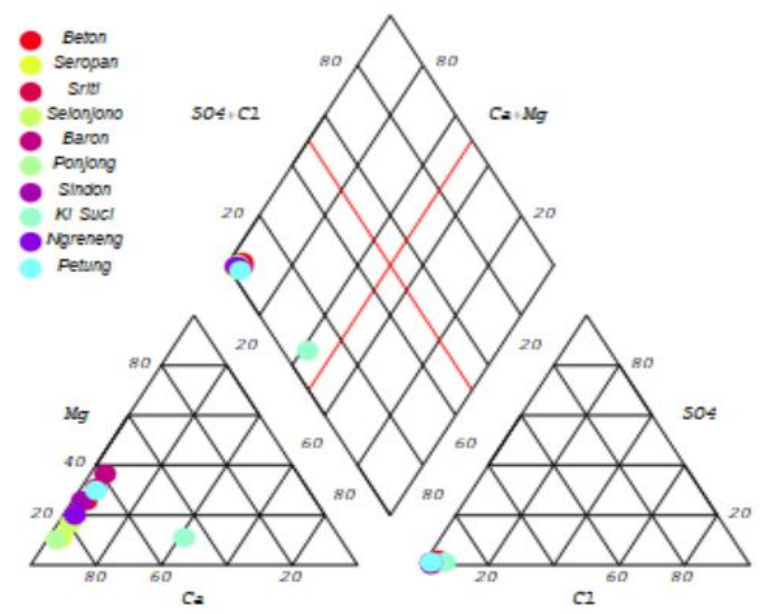

Figure 5. Piper diagram of all collected samples

\section{CONCLUSION}

From the tracer test that was conducted on March 16, 2012, it was found that Petung cave was directly connected with Sriti and Beton springs with a well-developed conduit. These interconnections are also confirmed by the deuterium and oxygen-18 ratios results. From breakthrough curve, the travel time of water from Petung cave to Sriti spring is about 2 hours. The travel time of water from Petung cave to Beton spring, on the other hand, was estimated to be about 10 hours. However, there was no an indication of hydraulic interconnection between injection point (Petung cave) to either Ngreneng cave, Seropan cave, Bribin cave, or Baron cave.

The slope of the regression line between deuterium versus oxygen-18 ratios which is less than 8 indicated that all of the water has undergone evaporation process. The deuterium and oxygen-18 ratios results also showed that water from Petung cave is not likely to flow to Bribin cave because the deuterium and oxygen-18 of water in Petung cave were much more enriched than in Bribin cave.

All of the samples collected from predetermined sampling points were assumed to be in contact with the karst formation (limestone) before exiting at the sampling point as it was shown from hydrochemical data that dominated by calcium and bicarbonate ions.

\section{REFERENCES}

[1] A. A. Patunru, "Access to Safe Drinking Water and Sanitation in Indonesia," Asia Pacific Policy Stud., vol. 2, no. 2, pp. 234-244, 2015.

[2] F. Aprian, Y. D. Setianingsi, U. Muntia, K. A. Susant, S. I. Wicakson, and A. Faru, "Rain Intensity Analysis as an Effort to Minimize Drought Impact in Gunung Kidul Regency in 2014 (in Indonesian)," Khazanah, vol. 6, no. 2, pp. 13-22, 2014.

[3] BPS-BPPD Kabupaten Gunung Kidul-, "Gunungkidul Dalam Angka 2015: Gunungkidul in Figures 2015." p. 280, 2015.

[4] E. Eiche, M. Hochschild, E. Haryono, and T. Neumann, "Characterization of recharge and flow behaviour of different water sources in Gunung Kidul and its impact on water quality based on hydrochemical and physico-chemical monitoring," Appl. Water Sci., vol. 6, no. 3, pp. 293-307, 2016.

[5] M. Widyastuti and E. Haryono, "Water Quality Characteristics of Jonge Telaga (Doline Pond) as Water Resources for the People of Semanu District Gunungkidul Regency," Indones. J. Geogr., vol. 48, no. 2, pp. 157-167, 2016.

[6] S. Fuchs, A. Silva, A. K. Anggraini, and F. Mahdariza, "Planning and installation of a drinking water treatment in Gunungkidul, Java, Indonesia," Water Sci. Technol. Water Supply, 
vol. 15, no. 1, pp. 42-49, 2015.

[7] T. N. Adji and Sudarmadji, "Hydrological Properties of Bribin Underground River System (Experience Learned for Seropan River System Project)," Integr. Water Resour. Manag. Semin., no. October, pp. 1-14, 2008.

[8] Satrio and P. Sidauruk, "Recharge Area Study of Underground River Water System in Gunungkidul - Yogyakarta Using Stable Isotopes $\delta 18 \mathrm{O}$ and $\delta 2 \mathrm{H}$," Journa Appl. Isot. Radiat., vol. 11, no. 2, pp. 87-98, 2015.

[9] P. Sidauruk, S. Satrio, and R. Prasetio, "Hydraulic interconnections study of SeropanNgreneng-Bribin uder ground rivers in Gunung Kidul karst area using tracer technique," Int. J. Water, vol. in press, no. x, 2017.

[10] Q. Yang, L. Wang, H. Ma, K. Yu, and J. Delgado, "Hydrochemical characterization and pollution sources identi fi cation of groundwater in Salawusu aquifer system of Ordos Basin, China," Environ. Pollut. J., vol. 216, pp. 340349, 2016.
[11] W. C. Teng, K. L. Fong, D. Shenkar, J. A. Wilson, and D. C. Y. Foo, "Piper diagram - A novel visualisation tool for process design," Chem. Eng. Res. Des., vol. 112, pp. 132-145, 2016.

[12] P. Sidauruk and E. R. Pujiindiyati, "Subsurface Flow and Surface Water Interactions Quantification in Gunung Kidul Karst Area Using Hydro- Chemical and Stable Isotopes Data Variations," Journa Appl. Isot. Radiat., vol. 11, no. 1, pp. 65-72, 2015.

[13] P. L. Smart and I. M. S. Laidlaw, "An Evaluation of Some Fluorescent Dyes for Water Tracing," Water Resour. Res., vol. 13, no. 1, pp. 15-33, 1977.

[14] P. Sidauruk, Satrio, and E. R. Pujiindiyati, "Assessment of Average Tracer Concentration Approach for Flow Rate Measurement and Field Calibration," Atom Indones., vol. 41, no. 3, pp. $151-159,2015$. 